\title{
Brachydactyly type A5
}

INSERM

\section{Source}

INSERM. (1999). Orphanet: an online rare disease and orphan drug data base.

Brachydactyly type A5. ORPHA:93389

Brachydactyly type A5 (BDA5) is a very rare cong enital malformation of the digits

characterized by absence of the middle phalanges (usually of digits 2 to 5), nail dysplasia and duplicated terminal phalanx of the thumb. 